\title{
MID-TERM EFFECTS OF THE FLAT RATE PERSONAL INCOME TAX IN HUNGARY
}

\begin{abstract}
The objective of the paper is to examine whether the advantages and disadvantages mentioned in the literature of the flat rate income tax could be observed in Hungary. Personal income tax data provided by the Hungarian National Tax and Customs Administration was used to check the arguments. It was found that the flat tax indeed favours richer taxpayers, and because of the family tax credits, it heavily favours families with children. Tax revenues declined as tax rates were cut, while the GDP growth rate was close to stagnant. Both of these developments go against the expectations of the flat tax supporters, although it has to be mentioned that the changes were made in the midst of a European- and world-wide depression, which could have distorted the pure effects of the new tax code. Although in many countries the flat rate tax was a positive signal for investors boosting foreign direct investments, the Hungarian government introduced extra taxes on some of the transnational companies in order to balance the budget (and compensate for the lost personal income tax revenues), which meant that there was a decline in the mood of the investors. There is some indication that some illegal activities are shifted to the legal domain: the ratio of those tax reporters who earned an annual income of HUF 2 million or higher has gone from $62.5 \%$ to $66.6 \%$ in the period of 2010-12.
\end{abstract}

Keywords: flat rate income tax, Hungary, tax statistics, income distribution

\section{INTRODUCTION}

Introducing a flat rate income tax has become a trend in the transition economies of Eastern and Central Europe. Estonia and Lithuania has had it since 1994; Latvia opted for it in 1995, Russia in 2001, Serbia in 2003, Slovakia and Ukraine in 2004, Georgia and Romania in 2005, Macedonia, Montenegro and Albania in 2007, the Czech Republic and Bulgaria in 2008, Belarus and Bosnia in 2009 and Hungary in 2011. Economists traditionally have attributed some advantages and disadvantages to such tax systems, but these theories were hard to test, because for a long time there were very few countries using flat rate income taxes (the rare exceptions included Hong Kong and Jamaica). But as the number of countries converting to the new tax code increased, more and more empirical evidence could be gathered.

Yet, the assessment of the flat rate income tax system is still very difficult, for several reasons. One of the major problems is that flat taxes affect people belonging to high and low income groups very differently, and therefore aggregated data that are usually provided by the tax authorities do not allow for sophisticated analysis. The midterm macroeconomic effects of the tax code change may be measured over 2 years, the longer

\footnotetext{
${ }^{1}$ Zoltan Bartha, PhD, Institute of Economic Theory, University of Miskolc, Hungary, zolib@hu.inter.net, http://gtk.uni-miskolc.hu/gei/bz_en, e-mail: zolib@hu.inter.net>
} 
term ones over 5 years according to Erdős ${ }^{2}$, which means that a country needs to sustain the system for at least 6-8 years in order to get some empirical data on the changes in the behaviour of taxpayers. In reality there were no countries that kept the same tax code for longer than a decade. Minor changes were introduced every year (about tax exemptions, or rate changes), and the possible return to the old system, or a possible change for something new was discussed regularly - something that surely affected the expectations of taxpayers. Also, the flat rate income tax system introduced usually was very different from the textbook version (e.g. several deductions and exemptions were allowed, which goes completely against the idea of having one single rate - see Table 1 for details). Finally, personal income is subject to social security contribution as well (a sort of payroll tax), and assessing the effects of income tax changes without including the social security contribution can lead to misleading results.

This paper is made up of three main parts. It offers a general literature review on the possible micro- and macroeconomic effects, advantages and disadvantages of the flat rate personal income tax. The review section is followed by the empirical assessment of the Hungarian experience, and the paper is concluded with the most important Hungarian findings.

\section{FLAT RATE INCOME TAX}

In the textbook version, a flat rate income tax describes a situation where the income is taxed at the same rate irrespective of the income of the taxpayer. This means that if the flat (or single) rate is $16 \%$ - as in case of Hungary - a taxpayer with an annual income of 1,000 euros pays a total of 160 as income tax, while one with an income of 1,000,000 pays 160,000 . A key point of the original suggestion made by Hall and Rabushka ${ }^{3}$ was that all income, including business and corporate income should be taxed at the same rate. Most tax codes however, do not follow this logic, so this paper only discusses personal income taxes.

The traditional alternatives of the flat rate (or single rate or linear) personal income tax are progressive and lump-sum taxes. Lump-sum taxes theoretically are great, because they do not alter economic behaviour, but are impossible to use. It is clear that people differ in their ability to earn an income, therefore the lump-sum tax would mean an unbearably high burden for some, and a pitiful sum for others. If, however, the lump-sum tax was adjusted to the abilities of the lowest income taxpayers, tax revenues would be very low. Because of these problems taxation is usually connected to the income of the individual.

The other alternative to flat taxes is the progressive tax system. Mirrlees ${ }^{4}$ showed that if taxpayers have different utility functions and different productivities (a quite realistic assumption) progressive taxes are a better alternative to linear ones, because they can lead to higher revenues. In other words a flat rate tax code would lead to lower burdens to more productive taxpayers. So why did so many Eastern and Central European countries opt for the flat rate system then? The explanations fall into two major categories: administrative-political arguments, and economic reasons.

\footnotetext{
2 T. Erdős, Egykulcsos jövedelemadó és gazdasági növekedés, Közgazdasági Szemle, LIX. February, 2012, pp. 109-138

${ }^{3}$ R. E. Hall, A. Rabushka, The Flat Tax, Stanford: Hoover Institute 1985.

${ }^{4}$ J. A. Mirrlees, An Exploration in the Theory of Optimal Income Taxation, in K.J. Arrow and M. D. Intrilligator (eds.), Handbook of Mathematical Economics, 1986.
} 
Table 1. Flat rate personal income tax (PIT) characteristics in Eastern and Central Europe (Source: own compilation based on EY: http://www.ey.com/GL/en/Services/Tax and KPMG: http://www.kpmg.com/GLOBAL/EN/SERVICES/TAX/Pages/default.aspx data)

\begin{tabular}{|c|c|c|c|c|}
\hline Country & $\begin{array}{c}\text { Flat rate } \\
\text { introduction } \\
\text { year }\end{array}$ & $\begin{array}{l}\text { Original } \\
\text { rate }(\%)\end{array}$ & $\begin{array}{c}2014 \\
\text { rate }(\%)\end{array}$ & Remarks \\
\hline Albania & 2007 & 10 & $13-23$ & $\begin{array}{l}\text { abandoned the flat rate system in } \\
2014\end{array}$ \\
\hline Belarus & 2009 & 12 & 12 & several deductions \\
\hline Bosnia & 2009 & 10 & 10 & $\begin{array}{l}\text { low income exemption and child } \\
\text { deduction }\end{array}$ \\
\hline Bulgaria & 2008 & 10 & 10 & $\begin{array}{l}\text { deductions for mortgage and } \\
\text { social security contribution }\end{array}$ \\
\hline $\begin{array}{l}\text { Czech } \\
\text { Republic }\end{array}$ & 2008 & 15 & $15-22$ & $\begin{array}{l}\text { abandoned the flat rate system in } \\
2013 \text { (several tax reliefs, and } \\
\text { solidarity surtax) }\end{array}$ \\
\hline Estonia & 1994 & 26 & 21 & $\begin{array}{l}1 \text { low income exemption and } \\
\text { child deduction }\end{array}$ \\
\hline Georgia & 2005 & 12 & 20 & $\begin{array}{l}\text { non-taxable deductions } \\
\text { depending on income level }\end{array}$ \\
\hline Hungary & 2011 & 16 & 16 & child deductions \\
\hline Latvia & 1995 & 25 & 24 & $\begin{array}{l}\text { non-taxable income, and several } \\
\text { deductions }\end{array}$ \\
\hline Lithuania & 1994 & 33 & 15 & $\begin{array}{l}\text { low income exemption and child } \\
\text { deduction }\end{array}$ \\
\hline Macedonia & 2007 & 10 & 10 & $\begin{array}{l}\text { deductions for social security } \\
\text { contribution }\end{array}$ \\
\hline Montenegro & 2007 & 15 & 9 & surtax in municipalities \\
\hline Romania & 2005 & 16 & 16 & $\begin{array}{l}\text { non-taxable deductions } \\
\text { depending on income level }\end{array}$ \\
\hline Russia & 2001 & 13 & 13 & several deductions \\
\hline Serbia & 2003 & 14 & 15 & $\begin{array}{l}\text { partially abandoned the flat rate } \\
\text { system in } 2010\end{array}$ \\
\hline Slovakia & 2004 & 19 & $19-25$ & $\begin{array}{l}\text { abandoned the flat rate system in } \\
2013\end{array}$ \\
\hline Ukraine & 2004 & 13 & 15 & $\begin{array}{l}\text { partially abandoned the flat rate } \\
\text { system in } 2007\end{array}$ \\
\hline
\end{tabular}

\subsection{Political and administrative arguments}

One of the arguments for the flat tax is that it is a lot easier to administer, meaning that the transaction cost of paying and collecting the tax can be significantly lowered. It is not uncommon that an individual draws income from more than one activity. Apart from earning a salary for the first job, one can have a second job as well, offer professional services as a private entrepreneur, earn returns on capital investments etc. In a traditional tax system these activities are taxed either separately, often with a different tax rate, or 
some of the income earned has to be accumulated, which poses further problems. In case of a flat tax the salary earned for the second job is taxed at the same rate as the first salary, so it is very easy to calculate the tax sum. With progressive rates however, it is quite likely that a second wage will bring the employee to a higher tax bracket (where income is taxed at a higher rate). In such a case the tax payable can only be determined if an estimate is made on the annual income, which is not that easy in the first place, and usually requires the employee to file complicated tax reports.

The suggestion of Hall and Rabushka ${ }^{5}$ was not simply about taxing all kinds of income with the same rate, but also about the elimination of exemptions and deductions. The elimination of exemptions and deductions can of course hurt vested interests, but it can also lower transaction costs a great deal. Basham and Mitchell ${ }^{6}$ mention the differences in the length of tax codes as an example (pp. 111-112): the US federal income tax generate 66,000 pages of regulation, while Hong Kong's entire tax code (the jurisdiction that has had the flat tax system since 1947) is only 200 pages long,

Longer and complicated tax codes have their own advantages, from a political point of view. Winer and Hettich ${ }^{7}$ point out that politicians tend to worry about the political cost per a dollar of revenue raised (basically, the political cost of the tax system) rather than the efficiency cost (measured as the deadweight loss of, and the transaction cost caused by taxes, the economic cost of the tax system). The political system therefore has the tendency to create high tax rates and more and more exemptions and deductions. The high rates are needed to produce the necessary revenues, and also make it look as if the rich pay more. Exemptions and deductions (even though they increase the transaction cost of taxing, and possibly even the deadweight loss, if other taxes have to be used to cover the holes in the budget) decrease the political cost of taxes. If deductions are possible after children and other dependants, health care and pension fund payments, tuition fees paid for the education of the children, long term savings, real estate and house purchases, charity donations etc., the political costs of the tax system may be lower, and politicians may be re-elected. The interesting point is that a large amount of deductions and exemptions move the tax system close to the flat rate (except for the poorest, who are usually exempted from tax payments in progressive systems, or even negative taxes may be in effect; and the richest, who will have to pay a lot of taxes even if they make use of all the exemptions and deductions). The major difference is in the transaction costs, which are considerably lower with a pure flat system.

Unfortunately the transaction cost advantage coming from the cancellation of exemptions and deductions could not be realised in Eastern and Central Europe. There is virtually no country where the flat tax was introduced in its pure form. As a matter of fact, most countries have two, and not one single tax rate, because if someone does not reach a certain minimum income, he is exempted from personal income tax payment (this is the case in the Baltic states, Romania etc. - see Table 1.). On the other hand, even in countries where the flat rate applies even to the lowest of incomes (Hungary, some countries in the

\footnotetext{
${ }^{5}$ R. E Hall, Rabushka, op.cit.

${ }^{6}$ P. Basham, D. Mitchell, Lessons from Abroad - Flat Tax in Practice, in: Clemens, J. (ed.): The Impact and Cost of Taxation in Canada: the case for flat tax reform, The Fraser Institute, 2008, pp. 103-143.

${ }^{7}$ W. Hettich, S.L. Winer, W., What Is Missed If We Leave Out Collective Choice in the Analysis of Taxation, National Tax Journal 52/2, 1998, pp. 373-89.
} 
Balkans), some kind of deduction is made possible, typically after children and long term savings.

The fact that many "flat rate" countries have a zero rate for the taxpayers with the lowest income, comes from the realisation that the new system hits the poor the hardest. More than that, Hettich and Winer ${ }^{8}$ suggest, that the flat rate is tough even on the middle class, which is the reason why they think that a flat rate tax cannot last in a democratic system. This suggestion may be backed by the fact that there were several countries that have abolished the flat tax recently: the Czech Republic, Slovakia and Albania among others. The Hettich-Winer ${ }^{9}$ argument can also explain why basically all countries have deductions built in their tax codes even after the introduction of the flat rate.

Finally, governments can introduce a flat rate system as an indication of their commitment to market liberalisation, and market forces in general ${ }^{10}$. Investors may be concerned about the dedication of the government to the market economy and the rule of law, and they may fear a predatory turn in taxation. For the concerned investors a flat rate system may be a positive, reassuring signal. In Eastern and Central Europe, where the market economy is still not that well rooted as it is in the West, such signals can be important.

If the signal hypothesis is true, there should be a strong correlation between the level of inward foreign direct investments (FDI) and tax systems in the Eastern and Central European region. Such connection however is hard to establish. The countries opted for the flat tax system in different years; FDI is determined by quite a few factors, such as global investment trends, geographic location of a country, other changes in government regulation etc.

Fig. 1. shows the case of three countries. The three countries were chosen because Estonia, Russia and Slovakia are most often used as an example in the literature addressing flat rate tax issues in Central and Eastern Europe. As the cultural and institutional background, as well as the size of these countries is different, their experience can illustrate the effects of the flat rate tax across a wide range of cisrcumstances. Russia is the one whose example backs the signal hypothesis the most. Because they switched to the new system in 2001, the data are shown from 1999 to 2006. It is clear to see that by 2003 the inward FDI almost quadrupled, and by 2006 it was fourteen times higher compared to 2001. But the period coincided with a lot of favourable events: Russia's institutions stabilised (the flat rate tax is part of that), a boom cycle started in investments, the price of commodities soared which lead to huge investments in the sector, and all these events expanded the size of the Russian consumer market by a great deal.

Estonia's case (1992-1999) is less convincing. Although the inward FDI was lower before the flat tax (1994), and it more than doubled by 1998, the trend is very hectic. Slovakia's example is even more confusing, and it does not seem to support the signal hypothesis at all. It has to be said that the end of the period in Slovakia's case is 2009, the year in which there was a huge drop in FDI globally.

\footnotetext{
${ }^{8}$ W. Hettich, S.L. Winer, Democratic Choice and Taxation: A Theoretical and Empirical Analysis, Cambridge University Press, 2005

${ }^{9}$ Ibidem.

${ }^{10}$ W. Hettich, S.L. Winer, What Is Missed....
} 
Fig 1. Inward foreign direct investments in Estonia, Russia and Slovakia, year of flat tax introduced=0, FDI in period $0=1(100 \%)$, (Source: own compilation based on UNCTAD data: http://unctad.org/en/pages/Statistics.aspx)

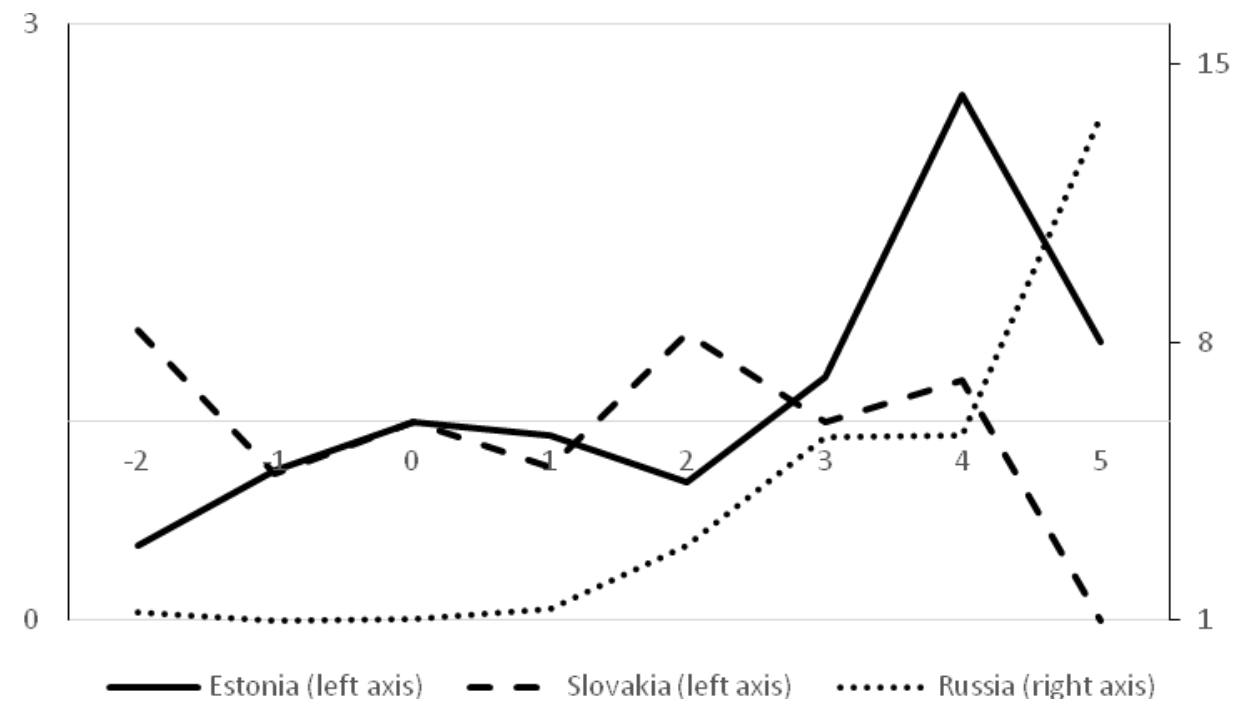

\subsection{Economic explanations}

Income taxes clearly have an effect on the two most important dimensions of the economy: growth and income distribution. The direction of the effect is not clear, though. Usually higher taxes slow down economic growth, and they have the potential to make income distribution more equal. But the redistribution process can be captured, meaning that higher taxes do not necessarily narrow income differences; and higher taxes can still generate growth in the Keynesian model. The different schools of economics could not agree on which of the two is more important, either. Kuznets ${ }^{11}$ argued that higher income differences were key in the generation of savings, which then could be used to finance higher investments, which on the other hand lead to robust economic growth. The quick growth rate and high per capita income can then be used to narrow the gap between the rich and the poor. Piketty ${ }^{12}$ on the other hand showed that wealth accumulates faster than the rate of economic growth, which meant in his interpretation that income differences will become larger and larger if no major steps are taken to close them down.

Although it is not quite the same division, but the growth vs. income distribution debate can also be imagined as a supply side vs. demand side approach to the economy. This paper discusses the possible effects of the flat tax from this perspective. First, the demand side arguments will be discussed, and the supply side will come second.

The demand side argument is generally based on the multiplier-accelerator effect common in Keynesian-based models. In order to have any change in the macroeconomic

${ }^{11}$ S. Kuznets, Economic Growth and Income Inequality, The American Economic Review, 45/1., March, 1955, pp. 1-28.

${ }^{12}$ T. Piketty, Capital in the Twenty-First Century, Harvard University Press, 2014. 
demand, the flat tax needs to change the tax burden and/or the income distribution. Usually the flat rate personal income tax changes both: it decreases the overall personal income tax revenue, and leaves more money in the pocket of the rich (more on this will follow in the supply side discussion). These two changes have opposing effects on the multiplier. The final effect will be shown in three steps, following the logic of Erdős ${ }^{13}$.

In step 1 we assume that the personal income tax revenue decreases by 100 units, leading to 100 extra income for the consumers. Some part of this additional income is saved, and the rest is consumed. The propensity to consume (c) and the propensity to save (s) show how the additional income is split between the two. The part that is consumed lands in the pocket of other economic agents, who will then split that additional income between saving and consumption, and so on. This is the basic multiplier effect which according to Erdös - takes around 2 years to go through the economy. But there are two more factors that need to be taken into consideration. On the one hand, when people gain additional income from the multiplying consumption, they have to pay income tax after it. So their additional consumption in not only determined by the propensity to consume, but also by the tax rate $(\mathrm{t}$, which in a flat tax system is ideally single rate and the same for all kinds of income). On the other hand some of the consumption will represent the purchase of foreign made goods. Because imported items were made abroad, the money spent on them moves outside the country, and therefore is no longer part of the multiplying income. The import part is shown by the propensity to import (m). The overall multiplier is very simple:

$$
\text { multiplier }=\frac{1}{1-c(1-t)(1-m)}
$$

So if the propensity to consume is $90 \%$, the tax rate is $20 \%$, and the propensity to import is $50 \%$, the multiplier is 1.5625 , meaning that a 100 -unit decrease in the personal income tax burden will generate 156.25 units of additional GDP. Christina and David Romer $^{14}$ calculated a tax multiplier for the USA. They found that its value is around 1 after the first year, and is a bit above 1 after two years, after which the effect levels off. The multiplier calculated by the Romers is considerably lower than the one given by our simple formula. The difference is even more striking if we consider that the propensity to import is considerably lower in the USA than the $50 \%$ that was used in the calculation above (if $\mathrm{m}=20 \%$, for example, the multiplier is above 2.3 ). The difference can be explained by a number of reasons: the tax cut may favour the rich, whose propensity to save is higher; prices may rise if the supply cannot adjust to the increased demand; interest rates may also rise, prompting people to save more.

Step 2 addresses the issue of the unequal distribution of the tax relief. Flat rate taxes leave more money in the pockets of the rich than in those of the middle class, while, if they are truly flat, with no exemption for the very poor, flat taxes increase the tax burden of the poor. As the rich tend to save a lot more (because they are in a position to be able to afford it), the introduction of the flat tax system leads to high propensity to save ratios, much higher than the $10 \%$ used in the initial calculation (again, if $c=60 \%$ instead of $90 \%$, the value of the multiplier drops to 1.3).

\footnotetext{
${ }^{13}$ T. Erdős, op. cit.

${ }^{14}$ C.D. Romer,. D.H. Romer, The Macroeconomic Effects of Tax Changes: Estimates Based on a New Measure of Fiscal Shocks, American Economic Review, 100/3, 2010, pp. 763-801.
} 
If the personal income tax is cut, and there is a decrease in the tax revenues, the budget deficit will likely increase. As a step 3, we have to consider the fact that in most countries the budget is not balanced in the first place, so it may well be that counter measures are required to fix the deficit problem. The government may raise other taxes, or cut spending. Both of these moves have a negative multiplier, which decreases the GDP, so it counters the positive changes generated by the flat tax reform.

Overall, the demand side analysis does not offer too much support for the flat tax. Even if the tax rates are cut, which should increase the GDP over the midterm, there are a lot of negative effects that counter the positive one. First of all, the income distribution will likely become more unequal, something that most demand side economist do not like, not least, because it increases the propensity to save, and decreases the multiplier. It also goes against the general Western, or Western European consensus of having tax codes that are focused heavily on income redistribution. And the flat tax increases the budget deficit in the demand side analysis, which leads to further problems, and it can completely negate the positive effect on growth.

The budget deficit effect is one of the key points where the demand and supply side arguments collide. For a demand side economist it is obvious that when the tax rate decreases, the tax revenue will decrease as well, and vice versa. This, however, is not so obvious if we take a look at the problem from the supply side, notably from the perspective of the taxpayer. As Wanniski ${ }^{15}$, one of the first propagators of the supply side argument, pointed out, a person is willing to sacrifice some of his free time because he needs to earn an income used to satisfy his needs. The more free time he sacrifices, and the more productive he is in his job, the higher income he will earn. Taxes affect this substitution process between leisure and work. The higher the tax rate, the less income can one realise when he sacrifices some free time. Progressive taxes therefore hurt at the most delicate point of the economy, where the highest value is created: at the level of entrepreneurs and managers. They are the ones who coordinate the work of thousands of employees, and make the company work. Because they earn a high salary, usually they are in the highest tax bracket (currently around 40-50\% in most countries with a progressive income tax). So when a manager or an entrepreneur thinks about sacrificing more leisure, he also has to face the fact that an additional hour worked, that might yield him 1000 extra euros, only gives him 300 or 400 extra, because the rest is paid as taxes or social security contribution.

The effect that income taxes have on the individual wanting to make the perfect split between leisure and work, is summarised by the income and the substitution effects. Income effect tells us that when the tax rate is decreased, the same amount of work yields higher income for the individual, prompting him to trade more work hours off for some free time, i.e. decrease his activity because he already has everything he needs, leading to a decrease in output. The substitution effect tells the opposite story. When there is a tax rate cut, the wage for the extra hour worked goes up from the previous 400 euros to, say, 500. The opportunity cost of free time is increased by 100 euros per hour. Because the opportunity cost of leisure is higher, the individual will more likely trade some of his leisure hours off for some work. The substitution effect thus leads to higher output. If we assume that the income effect and the substitution effect are similar in their impact, there is no point in wasting more time for the supply side analysis. Supply side economists,

${ }^{15}$ J. Wanniski, The Way the World Works, Fourth Edition, Regnery Publishing Inc, 1998. 
however, tell us that the substitution effect is always stronger than the income effect, i.e. individual effort and aggregate output increases when taxes are cut, and decreases when taxes are raised.

Fig 2. Annual percentage change of GDP in Estonia, Russia and Slovakia, year of flat tax introduced $=0$ (Source: own compilation based on IMF data: http://www.imf.org/external/pubs/ft/weo/2014/01/weodata/index.aspx)

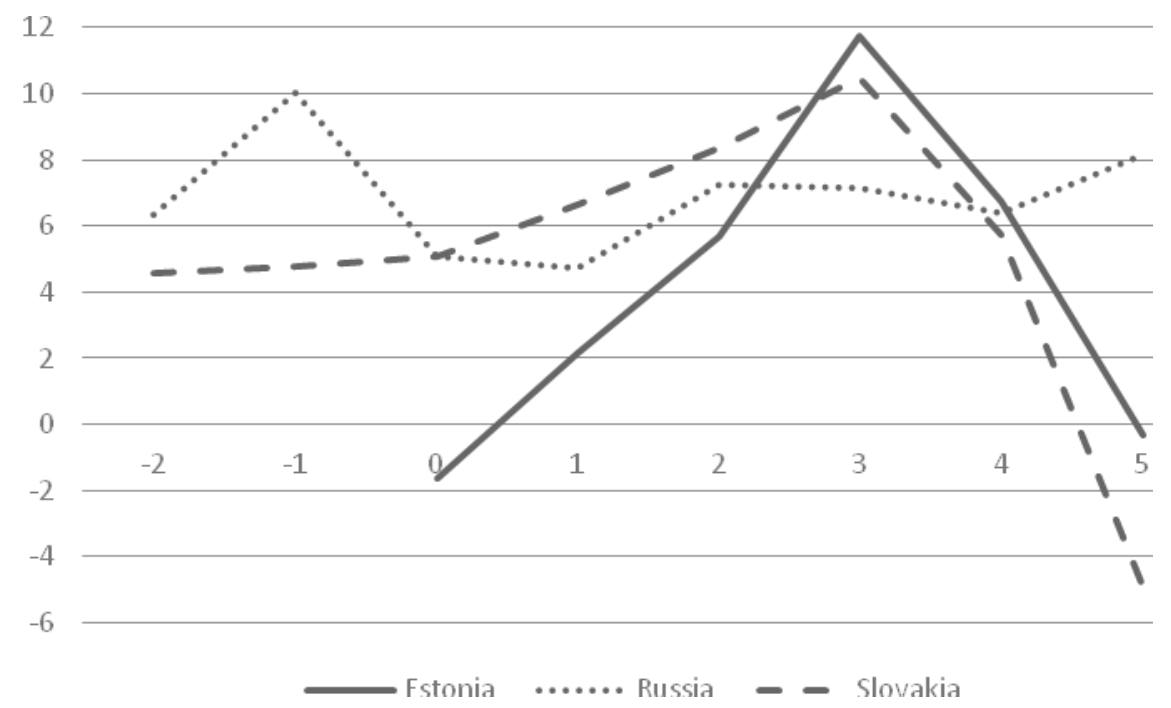

In reality there is a three-way trade-off when taxes are considered. The trade-off between leisure and work is there anyway, even if there are no taxes. When taxes are levied, however, one has the option to trade formal or official work (which can be taxed) off for informal or unofficial work (one that is illegal, so it is not taxed). The raising of taxes therefore has a double negative effect on output: because of the substitution effect individuals trade work off for leisure, decreasing their individual efforts; and they also trade legal work off for illegal one, decreasing the official output measured by the GDP, and also decreasing the tax base. The tax base is a key notion in the supply side argument, because by considering the tax base we can separate tax rates from tax revenues. If the tax rates are raised, the tax base shrinks (partly because people opt for more leisure, partly because they go illegal), and so tax revenues can also decrease, despite higher rates. On the other hand, if tax rats are cut, the tax base expands, so higher revenues may be collected despite lower tax rates.

The above idea is best described by the classic Laffer curve, named after Arthur Laffer, and introduced by Wanniski in his famous book, The Way the World Works ${ }^{16}$. Arguments based on the Laffer curve are very common across Eastern and Central Europe, and they were undoubtedly behind the flat tax reforms as well. It worth mentioning that in the 1970s, when Wanniski and Laffer came up with the idea, it was not 
uncommon that the highest marginal tax rate was above $80 \%$. In such conditions it is indeed quite a realistic assumption that a decrease in the highest tax rates actually expands the tax base so much that tax revenues increase. A lot has changed since then, and the top marginal rates have dropped substantially. The highest top rate on personal income in Europe is in Sweden at 57\%.

The top rate at which tax revenues can be maximised can be very different, depending on the characteristics of the countries. It depends on the rate at which the society tolerates, or even accepts tax evasion and tax fraud; it also depends on the quality of public goods the government is able to provide with the taxes it collects. As a result the high tax rates in some of the Eastern and Central European countries are not a very good indication of the true tax burden ${ }^{17}$. Indeed, the Russian tax reform showed that the Laffer curve works at much lower tax rates than one would expect. In 2000 Russia had marginal tax rates of $12 \%, 20 \%$ and $30 \%$, which was then changed to a single $13 \%$ rate in 2001 . As a result income tax revenues rose by $25.2 \%$ in 2001 , by $24.6 \%$ in 2002, by $15.2 \%$ in 2003 and a further $16 \%$ in 2004 . It meant that personal income tax revenues more than doubled in real terms in four years ${ }^{18}$. The huge increase was partly a result of general economic prosperity, increasing employment figures, individuals working more hours etc., but it was also a result of illegal activities being shifted to the legal side. Slonimczyk showed that the tax reform lead to a decrease in the fraction of informal employees. He estimates the drop in informal illegal activities to $2.5-4 \%$, and shows that the reform made it $14 \%$ less likely that someone entering the job market would engage in informal irregular activities ${ }^{19}$.

Evidence from other countries does not offer such strong support for the Laffer curve argument. Brook and Leibfritz argued that the Slovakian tax reform was revenue neutral ${ }^{20}$, which helps in improving the efficiency of the economy (taxation does not affect the resource allocation decisions). Other effects, however, could not be detected. If we take a look at Fig. 2., we can see that there is no clear connection between GDP growth and the flat tax. Russia has experienced high economic growth after the flat tax was introduced, but the same was true to the years before the 2001 reform. Slovakian growth picked up after the 2004 flat rate reform, but then it slumped in 2009, undoubtedly affected by the global crisis. Estonia's graph tells the same story: there is an initial spike, which is then followed by a big drop in 1999. Although after 1999 growth picked up again, and it almost reached a yearly average of $8 \%$ for the next 8 years.

Supply side economists have much stronger arguments for the flat rate tax, than demand side ones. But the evidence only partially backs those arguments, to say the least. It seems to work with Russia, but then the Russian economic model is regarded by few as a good example for a market economy. There are even signs that the Eastern and Central

17 S. Bozsik, Main Changes in European Tax Policies between 2007 and 2011, Theory Methodology Practice, 9/2, 2013, pp. 29-34.

${ }^{18}$ P. Basham, D. Mitchell, 2008, pp. 116-117

${ }^{19}$ F. Slonimczyk, The effect of taxation on informal employment: evidence from the Russian flat tax reform, in: H. Lehmann, K. Tatsiramos (eds.) Informal Employment in Emerging and Transition Economies (Research in Labor Economics, Volume 34), Emerald Group Publishing Limited, 2012, pp.55-99.

${ }^{20}$ A-M. Brook, W. Leibfritz, Slovakia's Introduction of the Flat Tax as Part of Wider Economic Reforms, OECD Working Papers nr. 448, 2005. 
European flat tax phenomenon will not last for very long. Slovakia and the Czech Republic have already abolished the single rate personal income tax. So did Albania, and the political elites of other countries are also debating the issue. The paper now tries to identify some patterns based on Hungary's experience.

\section{THE FLAT TAX REFORM IN HUNGARY}

The Hungarian flat tax reform was announced in 2010, and took effect in 2011. Although the personal income tax has a flat nominal rate, the effective rate can be very different for taxpayers with different income levels and/or with different number of children (see Table 2.). The main change was the switch from the system based on marginal rates of $17 \%$ and $32 \%$ to a $16 \%$ flat rate. Apart from the switch from a progressive to a linear tax code, the change also incorporated a significant nominal decrease in the tax rate.

Table 2. Personal income tax changes in Hungary, 2010-2014 (Source: own compilation).

\begin{tabular}{|c|c|c|c|c|c|}
\hline Tax category & 2010 & 2011 & 2012 & 2013 & 2014 \\
\hline $\begin{array}{l}\text { Nominal } \\
\text { rate }(s)\end{array}$ & $17 \%$ and $32 \%$ & $16 \%$ & $16 \%$ & $16 \%$ & $16 \%$ \\
\hline Tax base & $\begin{array}{c}\text { Aggregate } \\
\text { income } * 1.27\end{array}$ & $\begin{array}{c}\text { Aggregate } \\
\text { income } * \\
1.27\end{array}$ & $\begin{array}{l}\text { Aggregate } \\
\text { income * } \\
1.27 \\
\text { (above } 2.4 \\
\text { mil) }\end{array}$ & \multicolumn{2}{|c|}{ Aggregate income } \\
\hline $\begin{array}{l}\text { Low income } \\
\text { tax credit }\end{array}$ & $\max .17 \%$ & $\max .16 \%$ & \multicolumn{3}{|c|}{-} \\
\hline $\begin{array}{ll}\text { Family } & \text { tax } \\
\text { credit } & \end{array}$ & $\begin{array}{c}4,000 \\
\text { HUF/child/ } \\
\text { month* }\end{array}$ & \multicolumn{4}{|c|}{62,500 or $206,250 \mathrm{HUF} / \mathrm{child} / \mathrm{month}$} \\
\hline $\begin{array}{l}\text { Effective } \\
\text { rate(s) }\end{array}$ & $\begin{array}{l}0 \%-21.59 \% \\
\text { and } 40.64 \%\end{array}$ & $0 \%-20.32 \%$ & $\begin{array}{c}0 \%, 16 \% \\
\text { and } \\
20.32 \%\end{array}$ & $0 \%-16 \%$ & $\begin{array}{l}0 \%- \\
16 \%\end{array}$ \\
\hline
\end{tabular}

*The 2010 family allowance is not comparable with the credits of the successive years. A comparable amount would be around 20,000-25,000 HUF/child/month.

The overall tax burden was lowered even before the flat rate took effect, as the cut-off point of the lower bracket was raised from HUF 1.9 million to HUF 5 million in that year (which was around twice as high as the average annual gross salary). As the zero marginal rate was abolished earlier, these changes meant that the tax burden of the poor has risen considerably. To compensate for their losses, the tax credit system was put in place, which allowed the taxpayers with the lowest income to get a compensation that more or less equalled the tax they had to pay because of the cancellation of the zero rate bracket. This tax credit system was cancelled in 2012. So the effects of the cancellation of the zero marginal rate bracket were fully experienced in 2012. But, as Table 2. shows, many taxpayers still had an effective tax rate of zero, because of the very generous family tax credit. Starting from 2011, one of the parents from a family can reduce his/her tax base by HUF 62,500/month for each child (if they raise one or two children), or HUF 206,250/month for each child (if they raise three or more children). The family tax credit 
is so large, that many families actually don't have to pay personal income taxes; in fact, there are many families where the monthly income is so low that they cannot make use of the full credit. For this reason starting from 2014 families can reduce their social security contributions as well, if their tax base is not large enough. Overall it is clear that the redistribution effect of the new personal income tax code favours the high income families, and the ones that raise children.

\subsection{Tax revenues and tax burden}

Tax revenues soared in Russia after the tax rate reduction. Hungary's example tells an opposite story. Starting from 2008, there has been a continuous direct and/or indirect cut in the tax rates. Between 2008-10 tax rates were cut a bit (the lower rate went to $17 \%$ from $18 \%$, the higher one to $32 \%$ from $36 \%$ ), and the upper bound of the lower bracket was raised. From 2011 the flat rate of $16 \%$ took effect. The tax reduction is shown by the calculated effective rate (total tax paid divided by total tax base) as well: in 2008 it was $19.35 \%$, which was reduced to $14.03 \%$ by 2011 (see Table 3.). In 2012 the effective rate rose again, to $15.07 \%$, as a result of the abolishment of the low income tax credit.

Table 3. Key economic and tax related indicators of Hungary (Source: own compilation based on data by Hungarian Central Statistics Office and National Tax and Customs Administration)

\begin{tabular}{|c|c|c|c|c|c|}
\hline Key indicators & 2008 & 2009 & 2010 & 2011 & 2012 \\
\hline GDP growth (\%) & 0.893 & -6.767 & 1.054 & 1.571 & -1.665 \\
\hline Inflation $(\%)$ & 6.066 & 4.209 & 4.881 & 3.957 & 5.706 \\
\hline $\begin{array}{lll}\begin{array}{l}\text { Number } \\
\text { reporters }\end{array} & \text { of } \quad \text { tax } \\
\end{array}$ & 4646778 & 4492073 & 4567985 & 4495237 & 4463820 \\
\hline $\begin{array}{lc}\text { Total tax } \\
\text { (million HUF) }\end{array}$ & 9250248 & 8875284 & 8872478 & 8586188 & 9002918 \\
\hline $\begin{array}{l}\text { Family tax credit } \\
\text { (deducted from the } \\
\text { tax base, million } \\
\text { HUF) }\end{array}$ & - & - & - & 1126193 & 1151071 \\
\hline $\begin{array}{l}\text { Total tax payable } \\
\text { without deductions } \\
\text { (million HUF) }\end{array}$ & 2286050 & 2121836 & 2128077 & 1548342 & 1365952 \\
\hline $\begin{array}{l}\text { Deductions (million } \\
\text { HUF) }\end{array}$ & 502257 & 485965 & 645727 & 370492 & 10123 \\
\hline $\begin{array}{l}\text { Total tax paid (million } \\
\text { HUF) }\end{array}$ & 1790369 & 1643349 & 1486524 & 1204472 & 1356862 \\
\hline Effective tax rate & $19.35 \%$ & $18.52 \%$ & $16.75 \%$ & $14.03 \%$ & $15.07 \%$ \\
\hline $\begin{array}{l}\text { Ratio of reporters } \\
\text { below the annual } \\
\text { income of HUF } 2 \\
\text { million }(\%)\end{array}$ & 38.17 & 38.71 & 37.67 & 35.94 & 33.4 \\
\hline $\begin{array}{l}\text { Ratio of reporters } \\
\text { above the annual } \\
\text { income of HUF } 2 \\
\text { million }(\%)\end{array}$ & 61.83 & 61.29 & 62.33 & 64.06 & 66.6 \\
\hline
\end{tabular}

As nominal and effective tax rates declined, so did the tax revenues. While in 2008 the annual personal income tax revenue was as high as HUF 1,790 billion, by 2012 it 
dropped to 1,350 billion. With inflation taken into consideration (20\% during the 20092012 period), personal income tax revenues dropped by almost $40 \%$ in real terms. The picture is not so grim if we only consider the last two years, 2011 and 2012, when the flat tax was in effect: a 280 billion drop in the first year, then a 150 billion increase in the second year. On the one hand, this can be interpreted as the gradual appearance of the positive effects; but one cannot forget about the fact that the flat rate tax kicked in in two phases in Hungary: the low income tax credit (basically a zero rate for the poor) was still available in 2011, and then cancelled in 2012. 2013 data (which will only be available in October, 2014) might help in establishing a clearer trend, but in terms of the tax base 2012 and 2013 is not comparable (in 2012 the higher income taxpayers were taxed after a so called supergross base that included the $27 \%$ social security contribution paid by the employers - see Table 2.).

The comparison is made even more difficult by the effects of the global economic environment. Hungary started to lower the income tax rates right when the global crisis stroke. Unemployment rose, and the tax base naturally shrank as a result. One cannot realistically expect higher revenues in such conditions.

\subsection{Administrative considerations}

Flat rate taxes lower the transaction cost of taxpayers because they make it easier to file the tax. Ideally all types and all levels of income are taxed at the same rate, which makes it easier to pool together income coming from different sources, and basically ends the incentive to try and conceal certain types of income (the ones that are taxed at a higher rate). Hungary shows some improvement in this area. Although the corporate income tax is different from the personal income one (it is still progressive, with rates of $10 \%$ and $19 \%$ ), most of the personal incomes have the $16 \%$ rate: wages, service fees, private entrepreneur income, interest rates, dividends, capital gains, land rent.

Table 3. also shows that most of the tax deductions were eliminated by 2012. Deductions, once put in place, tend to become more and more complicated, and more and more widespread. The only major tax credit available in Hungary is the credit after children. The total tax base is reduced by around $12-13 \%$ because of it. It is questionable, whether the lack of major deductions will stay for a longer period, though. In 2013 the regulators made it possible to get tax deductions after long term insurance contracts. Further deductions were granted in 2014: after housing finance assistances, pension fund payments, and purchases of season tickets to sporting events.

\subsection{Supply side and the signal hypothesis}

As indicated above, and as it is shown by Table 3., although the effective rate has went down significantly in the period of 2008-2012, economic growth did not pick up at all. In fact, there was a decline in economic performance in 2009 (in the year in which virtually all European economies contracted), and in 2012. Growth barely went above $1 \%$ in the rest of the years. Hungary's GDP growth figures does not seem to back the idea that a tax cut, and especially the introduction of a flat rate, increases the incentives of the individuals to work more, and therefore leads to higher output overall. There are several explanations to the phenomenon.

First of all, in the 2008-2012 period growth cooled down globally, and in Europe especially. As the Hungarian economy is very open, the global contraction strongly affected the domestic economy. Second, Hungary had had major budget balance problems 
throughout the 2000s, which lead to a crisis of the government finances in the autumn of 2008 (solved with the help of the IMF and the EU). Starting from 2008 the budget balance has been the main priority of the Hungarian governments, contractionary fiscal policy measures were taken every year. These contractionary steps could easily overshadow the positive effects of the flat rate personal income tax. Despite the fact that the effective personal income tax rate went from $19 \%$ to $15 \%$ between 2008 and 2012, the overall tax burden has risen in the period. The general government revenue expressed in term of the GDP was $45.5 \%$ in 2008, 46.9\% in 2012 and 47.9\% in 2013 (IMF World Economic Outlook).

Table 4. Hungary's local currency government bond rating (Source: own compilation using data by Moody's)

\begin{tabular}{|c|c|c|c|c|c|c|}
\hline 2000 & 2006 & 2008 & 2009 & 2010 & 2011 & 2013 \\
\hline A1 & A2 & A3 & Baa1 & Baa3 & Ba1 & Ba1 \\
\hline
\end{tabular}

The Laffer curve argument tells us that government revenues can increase when tax rates are cut. But this is not what happened in Hungary. The personal income tax rate was cut, but personal income tax revenues decreased as well. The higher revenues came from the new taxes that the government levied after 2010. More than 25 new taxes were introduced, although some of them did not produce a high amount of revenue. As some of the older taxes were abolished, overall the number of taxes levied by the central government was increased from the 34 in 2010 to 41 in 2014. Such frequent changes in taxation hardly help in reducing the transaction costs of the process. The most important new taxes were levied on typically foreign owned, large corporation: banks, insurance companies, telecommunication firms, retail stores, public utilities, media enterprises ${ }^{21}$. The tax burden on banks was increased the most: the special bank tax levied an annual HUF 187 billion on financial corporations between 2010 and 2014, while there was a financial transaction fee introduced as well in 2013, yielding an annual HUF 300 billion for the budget (300 billion is a bit more than $1 \%$ of the annual GDP).

Tensions between the government and the banks lead to a massive drop in lending, which has probably contributed to the contraction of the economy. But the special taxes also battered the government's image in the eyes of foreign investors. Despite the fact that Hungary managed to keep the budget deficit under control, and despite the flat tax announced as early as 2010 (events that should have increased the trust of foreign investors), the expert's expectations on the country's perspectives got worse and worse. Table 4. shows Hungary's credit rating prepared by Moody's. When the 2008 crisis hit, the rating was at A2, which was lowered to A3 after the government finances crisis of October 2008. The rating has been in the Ba category (judged to be speculative) since 2011, the worst since the early 1990s.

By taking a closer look at Table 3., we can still find some evidence supporting the trade-off hypothesis of the supply side argument. As mentioned before, in case of a tax rate cut people may want to work more (substitution effect), and individuals engaged in illegal activities may rethink their strategy, and switch to the formal sector. Let's start with the second type of substitution. A private entrepreneur, who previously concealed the majority of his income because of the high tax rates, may feel that there is no longer need

\footnotetext{
${ }^{21}$ Papp Zs., Adóemelés Magyarországon - így fizet többet a lakosság. Napi Gzadaság, 28.01.2014.
} 
for such tricks if the tax rate is halved to $16 \%$, as it happened in 2011. If a considerable number of high income taxpayers think the same way, there should be a noticeable increase in the number of individuals reporting higher incomes. The last two rows of Table 3. might support this idea. The Hungarian tax office provides data about the distribution of taxpayers sorted by their tax base in the following structure: 1) tax base between 0 and 500 thousand forints; 2) 500-1 million; 3) 1-1.5 million; 4) 1.5-2 million; 5) 2-4 million; 6) above 4 million. The 2 million mark seems relevant in our analysis, because until 2010 the cut-off point for the higher tax bracket was below it. In 2010 the upper bound was raised to 5 million, and the number of reporters above an annual income of HUF 2 million increased to $62.3 \%$ from $61.3 \%$. In 2011, when the flat rate took effect, the ratio went up to $64 \%$, and in 2012 it reached $66.6 \%$. The change is rather dynamic, even though we have to consider the effect of inflation as well, that tends to drive up nominal wages.

While the flat rate income tax may create an incentive for richer individuals to report their full income to the tax office, the current social security contribution system works against that. Hungary has the second highest social security contribution rate $(28.5 \%$ paid by the employer, $18.5 \%$ paid by the employees) among the countries that have tried the flat tax (see table 5.). So the real burden for the high income taxpayers is not the $16 \%$ income tax, but the $18.5 \%$ individual contribution, and $28.5 \%$ paid by the employer. A further problem is that the value of the social security contribution is not in line with the value of services people get in exchange. Each individual is entitled to the same health care services, no matter how much he pays. So a cheesy private entrepreneur who only pays a monthly minimum of 5-6 thousand gets the same package as an honest one, paying several million. With pensions it is bit different, but again, pensions do not rise linearly as the social security contribution increases, and they are capped as well. Many countries apply a cap on social security payments for this reason, but the cap was abolished in Hungary, when the flat rate tax was announced.

The average gross monthly wage in Hungary is around HUF 230 thousand at the moment. If the employee does not have any children, and the firm is not entitled for some social security contribution relief (introduced in the 2010s to increase the employment rate among social cohorts with the highest job finding difficulties) the 230 thousand gross wage pays a 150 thousand net income, and costs 295 thousand to the firm. So an employee needs to create a value around the double of his net income because of the tax and social security contribution wedge. The wedge increased further on employers in 2012, when the low income tax credit was abolished. The government accepted a regulation that made it compulsory for employers to compensate for the net income losses caused by the cancellation of the low income tax credit ${ }^{22}$. Such interventions make the government policies look extremely negative from a supply side perspective.

There is no evidence for the leisure-work substitution effect. The OECD collects statistics on the average annual working time (in hours per worker). Here are the data for Hungary: 2005: 1 987; 2006: 1 983; 2007: 1 978; 2008: 1 982; 2009: 1 965; 2010: 1 959; 2011: 1976; 2012: 1888 (OECD: http://www.oecd-ilibrary.org/employment/averageannual-working-time_20752342-table8). The numbers do not indicate an increasing trend.

\footnotetext{
${ }^{22}$ Government Regulation nr. 299/2011 (December 22) on the expected rate of wage increase, 2011. http://jogszabalykereso.mhk.hu/cgi_bin/njt_doc.cgi?docid=143213.580592
} 
Table 5. Social security contribution rates in 2014 in the Eastern and Central European countries that has experimented with the flat tax (Source: own compilation based on EY data: http://www.ey.com/GL/en/Services/Tax)

\begin{tabular}{|c|c|c|}
\hline Country & Social contribution & Remark \\
\hline Albania & 27.9 & capped \\
\hline Belarus & 35 & capped \\
\hline Bulgaria & 30.5 & capped \\
\hline Czech Republic & 45 & \\
\hline Estonia & 33 & \\
\hline Hungary & 47 & \\
\hline Latvia & 35.09 & \\
\hline Lithuania & 34 & capped \\
\hline Macedonia & 27 & capped \\
\hline Montenegro & 34.47 & \\
\hline Romania & 44.25 & \\
\hline Russia & 30 & \\
\hline Slovakia & 48.6 & \\
\hline & &
\end{tabular}

\section{CONCLUSION}

The flat rate tax has six major advantages according to the literature: 1) decreases the transaction cost of taxation; 2) signals a market friendly attitude toward investors; 3 ) contributes to economic growth through the multiplier-accelerator effect (although real multipliers can be a lot lower than the ones suggested by theoretical models); 4) acts as an incentive to trade leisure and illegal activities off for work; 5) can therefore increase overall output; 6) can increase tax revenues despite the lower tax rates. It has its disadvantages as well: 1) may lead to an increased budget deficit; 2) favours the rich, by reducing their tax burdens, while the burden on the poor can easily increase.

The Hungarian experience shows the following. The tax introduced is not a true flat rate tax, because 1) it only involves personal income, and there are different rates for corporate income; 2) it is not without exemptions and deductions, as there is a substantial family tax credit available. Still, by 2012 the number of deductions went down considerably, moving the flat tax closer to its textbook version. From 2013 the number of deductions started going up again. There are also signs that higher income taxpayers started to report higher parts of their income officially, as the ratio of those tax reporters who earned an annual income of HUF 2 million or higher has gone from $62.5 \%$ to $66.6 \%$ in the period of 2010-12.

It was also found that the tax rate cuts did not lead to an increase in personal income tax revenues. Quite the contrary, whenever the effective rate dropped, so did the tax revenue. The government had to implement a lot of special taxes to compensate for the lost revenue, but that move has really eroded its reputation. The flat rate tax could not become a signal of market friendly attitude as a result. Economic growth did not pick up either, although it worth mentioning that the tax reform was introduced in a period when economic output was stagnating in most of the developed countries. The flat tax indeed favoured higher income taxpayers, especially after the low income tax credit was cancelled in 2012. Overall the Hungarian experience offers few arguments in favour of the 
tax, although the flat tax is obviously backed by those with higher income, and/or with children.

\section{REFERENCES}

[1] Erdős, T., Egykulcsos jövedelemadó és gazdasági növekedés, Közgazdasági Szemle, LIX. February 2012.

[2] Hall, R. E. - Rabushka, A, The Flat Tax, Stanford: Hoover Institute 1985.

[3] Mirrlees, J. A., An Exploration in the Theory of Optimal Income Taxation, in Arrow, K. J. and Intrilligator, M. D. (eds.), Handbook of Mathematical Economics 1986.

[4] Basham, P. - Mitchell, D., Lessons from Abroad - Flat Tax in Practice, in: Clemens, J. (ed.): The Impact and Cost of Taxation in Canada: the case for flat tax reform, The Fraser Institute 2008.

[5] Winer, S. L. - Hettich, W., What Is Missed If We Leave Out Collective Choice in the Analysis of Taxation, National Tax Journal 52/2,1998.

[6] Hettich, W. - Winer, S. L., Democratic Choice and Taxation: A Theoretical and Empirical Analysis, Cambridge University Press 2005

[7] Kuznets, S., Economic Growth and Income Inequality, The American Economic Review, 45/1., March 1955.

[8] Piketty, T., Capital in the Twenty-First Century, Harvard University Press 2014.

[9] Romer, C. D. - Romer, D. H., The Macroeconomic Effects of Tax Changes: Estimates Based on a New Measure of Fiscal Shocks, American Economic Review, 100/3, 2010.

[10] Wanniski, J., The Way the World Works, Fourth Edition, Regnery Publishing Inc 1998.

[11] Bozsik, S., Main Changes in European Tax Policies between 2007 and 2011, Theory Methodology Practice, 9/2, 2013.

[12] Slonimczyk, F., The effect of taxation on informal employment: evidence from the Russian flat tax reform, in: Lehmann, H. - Tatsiramos, K. (eds.) Informal Employment in Emerging and Transition Economies (Research in Labor Economics, Volume 34), Emerald Group Publishing Limited 2012.

[13] Brook, A-M. - Leibfritz, W., Slovakia's Introduction of the Flat Tax as Part of Wider Economic Reforms, OECD Working Papers nr. 448, 2005.

[14] Papp, Zs., Adóemelés Magyarországon - így fizet többet a lakosság. Napi Gzadaság, 28.01.2014.

[15] Government Regulation nr. 299/2011 (December 22) on the expected rate of wage increase,

2011. http://jogszabalykereso.mhk.hu/cgi_bin/njt_doc.cgi?docid=143213.580592

\section{ZRYCZALTOWANY PODATEK DOCHODOWY NA WĘGRZECH I JEGO SKUTKI}

Celem artykułu jest przedstawienie wad i zalet zryczałtowanego podatku dochodowego oraz skutki jego wprowadzenia na Węgrzech. Źródłem danych była Węgierska Krajowa Administracja Skarbowa oraz Administracja Celna. Zaobserwowano, że podatek dochodowy rzeczywiście sprzyjał bogatszym podatnikom, a ze względu na ulgi podatkowe $\mathrm{w}$ dużym stopniu sprzyjał również rodzinom z dziećmi. Dochody z podatków spadły $\mathrm{w}$ momencie gdy stawki podatkowe zostały zredukowane, a tempo wzrostu PKB było bliskie stagnacji. Na podstawie przeprowadzonych badań stwierdzono, że oba te wydarzenia były 
wbrew zwolennikom podatków zryczałtowanych i ich oczekiwaniom, choć należy wspomnieć, że zmiany te zostały dokonane w momencie europejskiego i światowego załamania, co mogłyby zniekształcić skutki nowego kodeksu podatkowego. Chociaż w wielu krajach podatek ryczałtowy był pozytywnym sygnałem dla inwestorów i podnosił zagraniczne inwestycje, rząd węgierski wprowadził dodatkowe podatki dla niektórych międzynarodowych firm w celu zrównoważenia budżetu (i zrekompensowania utraconych wpływów podatkowych od dochodów osobistych), co oznaczało, że nastąpił spadek nastrojów wśród inwestorów. Istnieją pewne wskazania, że niektóre nielegalne działania stały się legalnymi: stosunek podatników, którzy osiągnęli roczny dochód w wysokości 2 mln HUF lub wyższej wzrósł z 62,5\% do 66,6\% w latach 2010-12.

Słowa kluczowe: zryczałtowany podatek dochodowy, Węgry, statystyki podatkowe, dystrybucja dochodu

DOI:10.7862/rz.2014.hss.34

Przesłano do redakcji: czerwiec 2014

Przyjęto do druku: październik 2014 